\title{
Entamoeba histolytica: ANTIGENIC CHARACTERIZATION OF AXENIC STRAINS FROM BRAZIL
}

\section{SUMMARY}

Trophozoites from cultures of Entamoeba histolytica strains isolated and grown axenically in Brazil (ICB-CSP, ICB-462 and ICB-32) were used for immune sera production and for characterization of their antigens by using electrophoretic and glycoproteic profiles, in parallel with a standard strain isolated and kept under axenic conditions in USA (HK-9). Hyperimmune sera, presenting high antibody titers with homologous and heterologous antigens, were obtained. The four strains in study revealed similar and complex electrophoretic and glycoproteic profiles showing polypeptides with molecular weights ranging from 200 to less than $29 \mathrm{kDa}$. No significant differences were detected between the pathogenic and non-pathogenic strains.

KEY WORDS: Entamoeba histolytica; Axenic strains; Antigens.

\section{INTRODUCTION}

Studies on characterization of Entamoeba histolytica antigenic components have been widely performed and are relevant for the differentiation of strains as well as for the improvement of the immunodiagnostic methods.

Early attempts to characterize the antigenic composition of $\mathbf{E}$. histolytica gave poor results because amebae were grown with bacteria from intestinal tract of man, or in association with other protozoa ${ }^{17}$. Only after development of the axenic culture method ${ }^{5}$ it was possible to pre pare E. histolytica antigens without such contaminants.

The knowledge of the antigenic composition of axenically cultivated amebae is still limited.
Many investigators have pointed out the complexity of antigenic preparations used in the immunodiagnostic tests ${ }^{3,9,12}$.

Different strains of E. histolytica have common antigens $s^{2,4,12}$. The identification of specific antigens could increase the specificity of the immunologic reactions for the amebiasis diagnosis. Besides, as there are differences in the pathoge nicity of the strains, the antigenic characterization could be used as another parameter for differentiation of strains.

Several E. histolytica strains were isolated and are kept under axenic conditions in Brazil ${ }^{18}$. Very few immunological studies have been done with these strains.

(1) Department of Parasitology, Institute of Biological Science, Federal Minas Gerais University. Belo Horizonte, MG, Brazil.

(2) Department of Biology, Los Andes University, Venezuela.

(3) Department of Biochemistry and Immunology, Institute of Biological Science, Federal Minas Gerais University. Belo Horizonte, MG, Brazil.

Address for correspondence: Dr. Carlos Alberto P. Tavares. Departamento de Bioquímica e Imunologia, Instituto de Cièncias Biológicas, Universidade Federal de Minas Gerais. Caixa Postal 2486. CEP 30161 Belo Horizonte, MG, Brasil 
GUIMARĀES, S.; URDANETA, H.; SILVA, E. F. \& TAVARES, C. A. P. - Entamoeba histolytica: antigenic characterization of axenic strains from Brazil. Rev. Inst. Med. trop. S. Paulo, 33(1): 6-11, 1991.

The aim of the present study was to characterize antigenically pathogenic and non-pathogenic strains of E. histolytica, isolated and kept u.zder axenic conditions in Brazil.

\section{MATERIAL AND METHODS}

Entamoeba histolytica strains - Trophozoites from four strains of E. histolytica grown axenically in TPS-1 medium according to DIAMOND ${ }^{5}$ were used. Three of them were isolated and maintained under axenic conditions in Brazil, at the Amebiasis Laboratory (ICB/UFMG) in Belo Horizonte, Minas Gerais, by SILVA et $\mathrm{al}^{18}$ : ICB-CSP from a symptomatic patient and a high virulence strain; ICB-32 from a patient with non-enteric colitis and a low virulence strain; ICB-462 from an asymptomatic patient and a low virulence strain too. The fourth strain HK-9, isolated in USA by Frye (cited by GEIMAN \& BECKER $)^{7}$ from a symptomatic patient and kept in axenic conditions by DIAMOND ${ }^{5}$, was used as a standard strain.

Antigens - Mass culture of amebae was performed at $37^{\circ} \mathrm{C}$ in $250 \mathrm{ml}$ culture plastic flasks. Briefly, 72 to 96 hour cultures of amebae were washed five times in Phosphate Buffered Saline (PBS). The trophozoites masses from each E. histolytica strain were treated with protease inhibitors $^{14}$ and individually disrupted by ultrasonication. Whole extract, soluble extract and lipid free extract were prepared from homogenates of each strain. The soluble lipid free extract was obtained according to TANIMOTO-WEKI et $\mathrm{al}^{21}$, while soluble extract consisted of the supernatant obtained after centrifugation of whole extract at $20,000 \mathrm{x}$ g at $4^{\circ} \mathrm{C}$ during 2 hours. The protein content was determined by the method of LOWRY et $\mathrm{al}^{11}$.

Immune sera - Immune sera to E. histolytica were raised by immunizing New Zealand rabbits with four doses of antigen from each amebae strain (two animals/strain). The interval between each dose was fifteen days. In the first dose, animals were given $5 \times 10^{6}$ whole trophozoites by intraperitoneal route; in the second dose, whole extract ( $5 \mathrm{mg}$ protein) emulsified in Freund's Complete Adjuvant (v/v) on the rabbit's back; in he third dose, $5 \mathrm{mg}$ of protein with Freund's Incomplete Adjuvant (v/v) on the haunch. The booster dose of $1.5 \mathrm{mg}$ of protein with isotonic saline was given subcutaneously in the last third of the pads. The animals were bled to death 10 days after the booster dose, and the sera were titred by immunoenzimatic assay (ELISA).

ELISA $-2 \mu \mathrm{g}$ of whole extract from each strain $(20 \mu \mathrm{g}$ protein $/ \mathrm{ml}$ carbonate buffer $\mathrm{pH} 9.6)$ were adsorbed to microplates wells and incubated overnight at $4^{\circ} \mathrm{C}$. The next day, the plates were washed with PBS containing $0.05 \%$ Tween 20 and incubated with several dilutions of rabbit's immune sera as well as with negative and positive (infected rabbit) control sera at room temperature for $1 \mathrm{~h}$. All sera were diluted up to $1: 20480$ in PBS containing $0.3 \%$ casein. The plates were washed as before and $100 \mu \mathrm{l}$ of peroxidase conjugate goat anti-rabbit IgG (diluted in PBS-casein) was added to each well of the plates and incubated as above for $1 \mathrm{~h}$. After the wells had been washed in PBS-Tween 20,100 $\mu$ l of $0.002 \%$ 0-phenylenediamine (Sigma) in buffer solution (pH 5.0) containing $46 \mathrm{mM} \mathrm{Na}_{2} \mathrm{HPO}_{4}, 100$ $\mathrm{mM}$ citric acid and $0.012 \% \mathrm{H}_{2} \mathrm{O}_{2}$ was added to each well. The reaction was interrupted after 30 min at room temperature by the addition of 20 $\mu \mathrm{l}$ of $4 \mathrm{~N} \mathrm{H}_{2} \mathrm{SO}_{4}$. Intensity of colour developed in each well was recorded as optical density (OD) at $492 \mathrm{~nm}$ wavelengh.

Sodium dodecyl sulfate polyacrylamide gel electrophoresis (SDS-PAGE) - Samples of soluble extract and soluble lipid free extract $(60 \mu \mathrm{g}$ protein) from each strain were solubilized in sample buffer $(\mathrm{v} / \mathrm{v})$ containing $10 \%$ SDS and $5 \%$ 2-mercaptoethanol and heated for three minutes. Electrophoresis was performed, as described by LAEMMLI ${ }^{10}$, in a 5 to $12 \%$ gradient for separating gels. Molecular weight markers (Sigma) were always used. After electrophoresis, gels were stained with Comassie blue or transferred to nitrocellulose sheets.

Concanavalin-A (Con-A) blot - Glycoproteins binding Con-A were detected on nitrocellulose sheets by a modification of the method of HAWKES ${ }^{8}$. Proteins of soluble extracts and soluble lipid free extracts were previously separated by SDS-PAGE as described above and transferred to nitrocellulose sheet $(0.45 \mu \mathrm{m})$. After transference, the sheets were washed with PBS containing $0.3 \%$ Tween 20 and imersed in lectin buffer (20 $\mathrm{mM}$ Tris, $500 \mathrm{mM} \mathrm{NaCl}, 1 \mathrm{mM} \mathrm{MnCL}$ and 
GUIMARÃES, S.; URDANETA, H.; SILVA, E. F. \& TAVARES, C. A. P. - Entamoeba histolytica: antigenic characterization of axenic strains from Brazil. Rev. Inst. Med. trop. S. Paulo, 33(1): 6-11, 1991.

$0.03 \%$ Tween 20 ) containing $50 \mathrm{mg} / \mathrm{ml}$ Con-A (Sigma) for 2 hours at room temperature with gentle rotation. After incubation the supernatant was removed and the sheets were washed three times (15 minutes each) in lectin buffer. The wash solution was removed and replaced with a solution containing $50 \mu \mathrm{g} / \mathrm{ml}$ horseradish peroxidase (Sigma) in lectin buffer. After $1 \mathrm{~h}$ at room temperature with gentle rotation, the sheets were washed twice, $10 \mathrm{~min}$ each with lectin buffer, followed by two $10 \mathrm{~min}$ washes in PBS alone. Glycoprotein binding Con-A were detected using the following substrate solution: $120 \mathrm{mg}$ of 3,3'-diaminobenzidine (Sigma) in 120 $\mathrm{ml}$ of PBS and $60 \mathrm{mg}$ of 4-chloro, 1- $\alpha$-naphthol (Sigma) dissolved in $20 \mathrm{ml}$ of methanol and 100 $\mathrm{ml}$ of PBS, $100 \mu \mathrm{l}$ of $30 \% \mathrm{H}_{2} \mathrm{O}_{2}$.

\section{RESULTS}

\section{Immune sera production}

Rabbit hyperimmune sera to E. histolytica were raised by immunizing the animals with the antigens from HK-9, ICB-CSP, ICB-42 and ICB-462 strains. When tested in ELISA with antigens from homologous and heterologous strains they showed titers ranging from 2560 to 10240 (Table 1).

\section{Electrophoretic characterization of soluble amebae extracts}

Samples of soluble extracts and soluble lipid free extracts from each axenic strain were characterized by polyacrylamide electrophoresis (Figures 1 and 2). Better results were seen when soluble lipid free preparations were used presenting more distinct polypeptide bands in SDSPAGE (Figure 2). The strains revealed a complex profile of polypeptide bands with molecular weights (M.W.) ranging from $200 \mathrm{kDa}$ to less than

TABLE 1

Sera titers in ELISA of rabbits immunized with antigens from axenic strains of E. histolytica.

\begin{tabular}{lrccr}
\hline \multirow{2}{*}{ Antigens } & \multicolumn{4}{c}{ Anti-E. histolytica sera titers } \\
\cline { 2 - 5 } & HK-9 & ICB-CSP & ICB-462 & ICB-32 \\
\hline HK-9 & 5120 & 2560 & 2560 & 10240 \\
ICB-CSP & 10240 & 5120 & 5120 & 5120 \\
ICB-462 & 5120 & 5120 & 5120 & 10240 \\
ICB 32 & 5120 & 5120 & 2560 & 5120 \\
\hline
\end{tabular}

$20 \mathrm{kDa}$ (Figures 1 and 2). The Brazilian strains ICB-CSP, ICB-462 and ICB-32 showed similar profiles and did not differ significantly from the

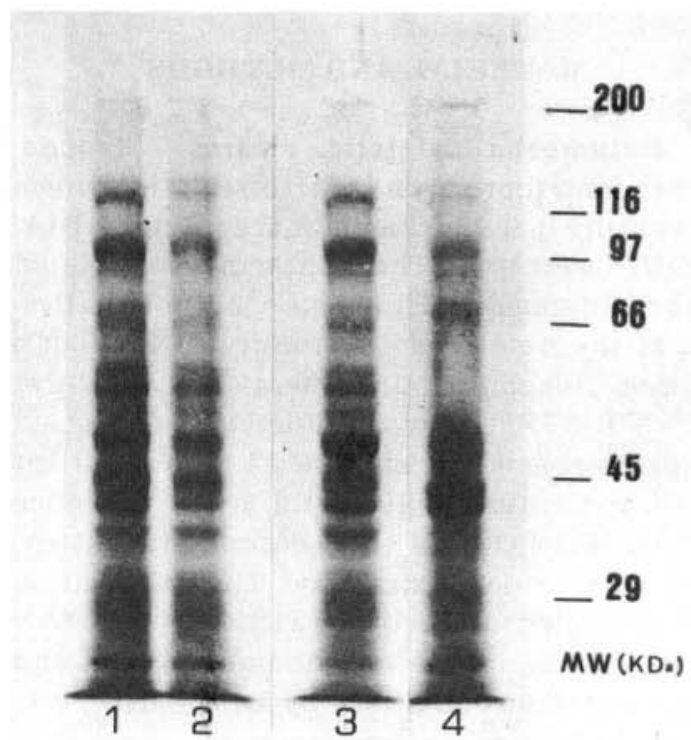

Fig. 1 - Sodium dodecyl sulphate polyacrylamide gel electro phoresis (SDS-PAGE) of soluble extracts from axenic strains of E. histolytica. (1) ICB-CSP, (2) ICB-32, (3) ICB-462, (4) HK-9 The protein samples ( $60 \mu \mathrm{g} /$ well) were analysed by using gradient gel $5-12 \%$ acrylamide and Comassie blue stainning.

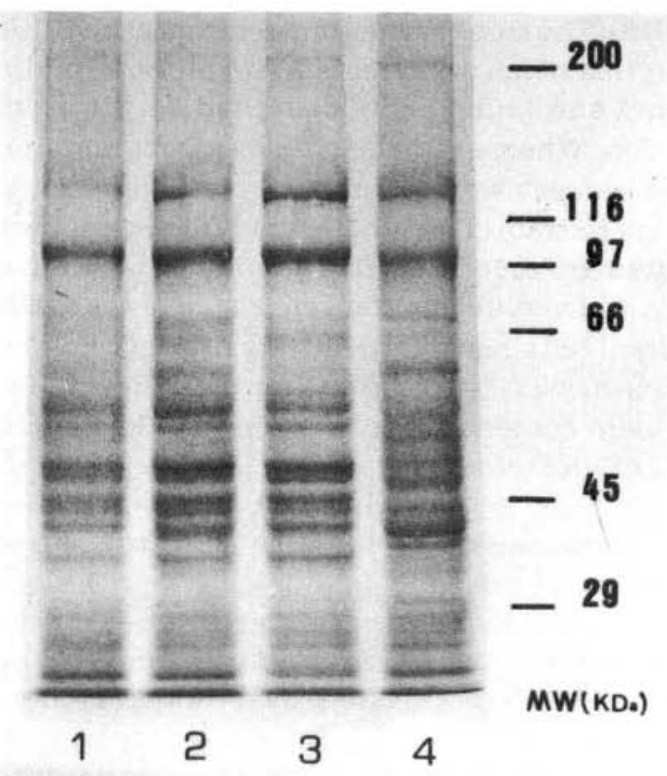

Fig. 2 - Sodium dodecyl sulphate polyacrylamide gel electro phoresis (SDS-PAGE) of soluble lipid free extracts from axenic strains of E. histolytica. (1) ICB-32, (2) ICB-CSP, (3) ICB-462, (4) $\mathrm{HK}-9$. The protein samples $(60 \mu \mathrm{g} /$ well) were analysed by using gradient gel $5-12 \%$ acrylamide and Comassie blue stainning. 
GUIMARĀES, S.; URDANETA, H.; SILVA, E. F. \& TAVARES, C. A. P. - Entamoeba histolytica: antigenic characterization of axenic strains from Brazil. Rev. Inst. Med. trop. S. Paulo, 33(1): 6-11, 1991.

standard strain HK-9. Most of the polypeptides detected in SDS-PAGE were observed in all the four strains analysed.

\section{Glycoproteic characterization of soluble amebae extracts}

Glycoproteins binding Con-A present in soluble extracts and soluble lipid free extracts were detected in nitrocellulose membrane (F1gure 3). The four strains showed a complex and apparently homogenous glycoproteic profile. The glycoproteic profiles of the strains were very similar without significant differences, showing glycoproteins with molecular weight ranging from 200 $\mathrm{kDa}$ to $29 \mathrm{kDa}$. When soluble lipid free extracts were used, the bands observed were more clear (Figure 3B).

\section{DICUSSION}

The characterization of the antigenic components of E. histolytica has been one of the objectives in studying this parasite. Their definition is relevant for the improvement of diagnostic methods and for differentiation of axenic strains.

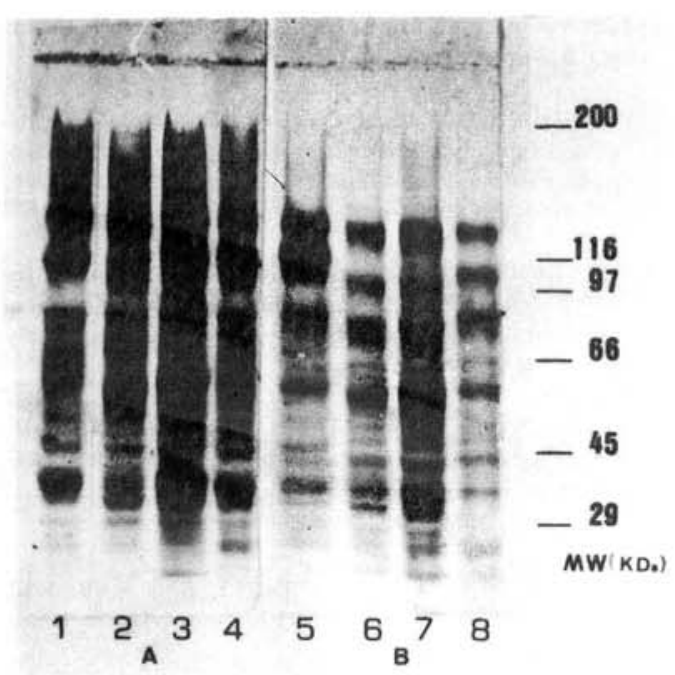

Fig. 3 - Glycoproteic profile of soluble lipid free extracts (A) and soluble extracts (B) from axenic strains of E. histolytica. (1) HK-9, (2) ICB-462, (3) ICB-CSP, (4) ICB-32, (5) HK-9, (6) ICB-462, (7) ICB-CSP, (8) ICB-32. Glycoproteins were detected in nitrocellulose sheets by using Con-A. The protein samples $(60 \mu \mathrm{g} /$ well) were previously fractionated by SDS-PAGE.
Antigens from Brazilian axenic strains (ICSCSP, ICB-32 and ICB-462) and from the standard strain HK- 9 showed to be similarly immunogenic, as well as were able to induce production of antibodies showing high titres with homologous and heterologous antigens. This cross-reactivity suggests the occurrence of common antigens between $\mathbf{E}$. histolytica strains and have been demonstrated by other investigators ${ }^{2.4 .9}$.

According to SDS-PAGE analyses, soluble extracts of E. histolytica strains revealed complex and similar electrophoretic and glycoproteic profiles and did not differ significantly one from another. Soluble extracts showed more distinct electrophoretic and glycoproteic profiles than whole extracts. Better resolution was observed when soluble lipid free extract was used. Many polypeptides detected in SDS-PAGE showed molecular weight identical or nearly to those detected by AUST-KETTIS et $\mathrm{al}^{2}$ and MATHEWS et $\mathrm{al}^{12}$.

Several glycoproteins detected in nitrocellulose membrane showed the same molecular weight to those polypeptides observed in polyacrylamide gels, which demonstrated the glycoproteic composition of many antigens of E. histolytica. Furthermore, in the soluble preparations we detected glycoproteins with molecular weights similar to those detected on the surface of the parasite by others investigators ${ }^{1.2,13,14}$. According to AUST-KETTIS et $\mathrm{al}^{2}$, this coincidence could be explained considering the pronounced phagocytic power and the rapid and continuous cell membrane turnover allowing the presence of antigenic components both on and within the amebae.

We showed that axenic E. histolytica strains from Brazil, present a pattern as complex as others strains described in the literature. None of polypeptides identified could differentiate between pathogenic and non-pathogenic strains.

Recent studies by SARGEAUNT and co-workers have demonstrated that E. histolytica strains isolated from patients with dysentery show isoenzymatic patterns that differ from those isolated from asymptomatic carriers ${ }^{15}{ }^{16}$. More recently, it has been reported that monoclonal antibodies (MAbs) and DNA probes also could distinguish between pathogenic and non-patho- 
GUIMARĀES, S.; URDANETA, H.; SILVA, E. F. \& TAVARES, C. A. P. - Entamoeba histolytica: antigenic characterization of axenic strains from Brazil. Rev. Inst. Med. trop. S. Paulo, 33(1): 6-11, 1991

genic strains ${ }^{6,19,20,22}$. However, in spite of the several studies on amebae antigenicity, the immunology of the components responsible for pathogenicity or nonpathogenicity is not well understood.

\section{RESUMO}

\section{Entamoeba histolytica: caracterização antigê- nica de cepas axênicas do Brasil.}

Trofozoítos obtidos de cultura de Entamoeba histolytica isoladas e axenizadas no Brasil (ICB-CSP, ICB-462 e ICB-32) foram utilizados para a produçāo de soros imunes em coelhos e para a caracterização de antígenos através dos seus perfis eletroforético e glicoproteico, em paralelo com uma cepa padrão isolada e axenizada nos Estados Unidos (HK-9). Obtiveram-se soros hiperimunes, reativos frente aos antígenos homólogos e heterólogos. As quatro cepas em estudo apresentaram perfis eletroforético e glicoproteico complexos e semelhantes, compostos por polipeptídeos com pesos moleculares variando de $200 \mathrm{kDa}$ a menos de $29 \mathrm{kDa}$. Não se detectaram diferenças significativas entre as cepas patogênicas e não patogênicas.

\section{ACKNOWLEDGMENTS}

We particularlly thank Dr. Antoniana Ursine Krettli for her critical review of this work. We also thank Mr. João da Costa Viana, Ms. Marinete L. Ludgero and Ms. Edna Pires for their technical assistance. This work was supported by CNPq, FINEP and FAPEMIG.

\section{REFERENCES}

1. ALEY, S. B. SCOTT, W. A. \& COHM, Z. A. - Plasma membrane of Entamoeba histolytica. J. exp. Med., 152: $391-404,1980$.

2. AUST-KETTIS, A.; THORSTENSON, R. \& UTTER, G. - Antigenicity of Entamoeba histolytica strain NIH-200. A survey of clinically relevant components. Amer. J. trop. Med. Hyg., 32: 512-522, 1983.

3. BOS, H. J. \& WANDERGREIND, R. J. - Virulence and toxicity of axenic Entamoeba histolytica. Nature, 265: $341-343,1977$

4. CHANG, S. M.; LIN, C. M.; DUSANIC, D. G. \& CROSS, J. H. - Antigenic analyses of two axenized strains of Entamoeba histolytica by two-dimenstonal immunoelectrophoresis. Amer. J. trop. Med. Hyg., 28: 845-853, 1979.
5. DIAMOND, L. S. - Techniques of axenic cultivation of Entamoeba histolytica Schaudinn, 1903, and E. histolytica like amebae. J. Parasit., 54: 1047-1056, 1968.

6. GAR FINKEL, L. I.; GILADI, M.; HUBER, M.; GITLER, C.; MIRELMAN, D.; REVEL, M. \& ROZENBLATT, S. DNA probes specific for Entamoeba histolytica possessing pathogenic and nonpathogenic zymodemes. Infect. Immun., 57: 926-931, 1989

7. GEIMAN, Q. M. \& BECKER, C. E. - In vitro growth and metabolism of Entamoeba histolytica. Ann. N. Y. Acad. Sci., 56: 1048-1056, 1953.

8. HAWKES, R. - Identification of Concanavalin A - binding proteins after sodium dodecyl sulfate - gel electrophoresis and protein blotting. Analyt. Biochem., 123: 143-146, 1982.

9. KRUPP, I. M. - Definition of antigenic pattern of Entamoeba histolytica, and immunoelectrophoretic analysis of the variation of patient response to amebic disease. Amer. J. trop. Med. Hyg., 26: 387-392, 1977

10. LAEMMLI, U. K. - Cleavage of structural protein during the assembly of the head of bacteriophage $T$. Nature, 227: $680-685,1970$.

11. LOWRY, M. N.; ROSENBROUGH, N. J.; FARR, A. L. \& RANDALL, R. J. - Protein measurement with the Folin reagent. J. biol. Chem., 193: 265-275, 1951.

12. MATHEWS, H. M.; MOSS, D. M. \& VISVESVARA, G. $\mathbf{S}$ - Analyses of antigens from membrane and soluble fractions of Entamoeba histoly tica. J. Protozool., 33: 328-334, 1986.

13. MUNOZ, M. L. M.; VALE, H.C. \& CALDERON, J. - Redistribución de antigenos superficiales de entamoebas y su caracterización imunoquimica. Arch. invest. Méd. (Méx.), 9 (Supl. 1): 183-190, 1978.

14. PARKHOUSE, M.; CID, M. E. \& CALDERON, J. - Identificación de antigenos de membrana de Entamoeba histolytica con anticuerpos de pacientes de amibiasis. Arch. invest. Méd. (Méx.), 9 (Supl. 1): 211-218, 1978.

15. SARGEAUNT, P. G. - Zymodemes of Entamoeba histolytica. In: RAVDIN, J. I. ed. - Amebiasis: human infection by Entamoeba histolytica. New York, John Wiley \& Sons, 1988. p. 370-387.

16. SARGEAUNT, P. G.; WILLIAMS, J. E. \& GRENE, J. D - The differentiation of invasive and non-invasive Entamoeba histolytica by isoenzyme electrophoresis. Trans. roy. Soc. trop. Med. Hyg., 72: 519-521, 1978.

17. SEN, A.; GHOSH, S. N.; MUKERJEE, S. \& RAY, J. C - Antigenic structure of Entamoeba histolytica. Nature, 192: 893,1961

18. SIlVA, E. F.; CARVALHO, M. G. \& BRANDÁO, M. G. L. - Monoxenização, axenizaçāo e cultivo de amostras de Entamoeba histolytica isoladas no Brasil de pacientes sintomáticos e assintomáticos. In: CONGRESSO BRASILEIRO DE PARASITOLOGIA, 6., Belo Horizonte, 1981. Resumos. p. 18. 
GUIMARÄES, S.; URDANETA, H.; SILVA, E. F. \& TAVARES, C. A. P. - Entamoeba histolytica: antigenic characterization of axenic strains from Brazil. Rev. Inst. Med. trop. S. Paulo, 33(1): 6-11, 1991.

19. STRACHAN, W. D.; CHIODINI, P. L.; SPICE, W. M.; MOODY, A. H. \& ACKERS, J. P. - Immunological differentiation of pathogenic and non-pathogenic isolates of Enta. moeba histolytica. Lancet, 1: 561-563. 1989.

20. TACHIBANA, H.; KOBAYASHI, S.; KATO, Y.; NAGA. KURA, K.: KANEDA, Y. \& TAKEUCHI, T. - Identification of a pathogenic isolate-specific $30,000 \mathrm{Mr}$ antigen of Entamoeba histolytica by using a monoclonal antibody. Infect. Immun., 58: 955-960, 1990.

21. TANIMOTO-WEKI, M.; AGUIRRE-GARCIA, J.; SAN CHEZ, M. E. \& SEPÚLVEDA, B. - Inducción de inmu- nidad protectora antiamibiana en el hámster por medio de antigeno soluble deslipidizado. Arch. invest. Med. (Méx.), 17 (Supl. 1): 233-235, 1986.

22. TANNICH, E.; HORSTMANN, R. D.; KNOBLOCH, J. \& ARNOLD, H. H. - Genomic DNA differences between pathogenic and non-pathogenic Entamoeba histolytica. Proc. nat. Acad. Sci. (Wash.), 86: 5118-5122, 1989.

Recebido para publicação em 14/3/1990. Aceito para publicação em 30/10/1990. 